$$
\begin{gathered}
\text { DOE/PC/94/18--06 } \\
\text { BESEIVEO } \\
\text { AUG } 1: 1998 \\
\text { OSTI }
\end{gathered}
$$

\title{
Automated Boiler Combustion Controls for Emission Reduction and Efficiency Improvement
}

\author{
Quarterly Report \\ July 15 - September 15, 1995
}

Work Performed Under Contract No.: DE-FC22-94MC94118

For

U.S. Department of Energy

Office of Fossil Energy

Federal Energy Technology Center

P.O. Box 880

Morgantown, West Virginia 26507-0880

By

Control Techtronics International

99 S. Cameron Street

Harrisburg, Pennsylvania 17101-2805 


\section{Disclaimer}

This report was prepared as an account of work sponsored by an agency of the United States Government. Neither the United States Government nor any agency thereof, nor any of their employees, makes any warranty, express or implied, or assumes any legal liability or responsibility for the accuracy, completeness, or usefulness of any information, apparatus, product, or process disclosed, or represents that its use would not infringe privately owed rights. Reference herein to any specific commercial product, process, or service by trade name, trademark, manufacturer, or otherwise does not necessarily constitute or imply its endorsement, recommendation, or favoring by the United States Government or any agency thereof. The views and opinions of authors expressed herein do not necessarily state or reflect those of the United States Government or any agency thereof. 


\section{DISCLAIMER}

Portions of this document may be illegible in electronic image products. Images are produced from the best available original document. 
1.0 EXECUTIVE SUMMARY . . . . . . . . . . . . . . . . . 1

2.0 INTRODUCTION . . . . . . . . . . . . . . . . . . . . . . 3

3.0 DESCRIPTION OF ACTIVITIES DURING THE PAST QUARTER . • . . 4

4.0 STATUS OF TASKS . . . . . . . . . . . . . . . . . . 5

5.0 NEXT QUARTER ACTIVITIES . . . . . . . . . . . . . . . 8

6.0 FOREIGN TRAVEL REPORT . . . . . . . . . . . . . . . . . . . . . 9

7.0 MANAGEMENT SUMMARY REPORT . . . . . . . . . . . . . . . . 10 
Control Techtronics International. (CTI) is conducting a project to reduce air emissions and increase efficiency in coal fired boilers in Krakow, Poland and to create a commercial venture in Poland which can act as a leader for efficient combustion in boilers throughout the region. In Budget Period one (first year), CTI demonstrated both efficiency improvement and emission reduction at MPEC's Baliclo district heating plant in the Widok section of Krakow.

In the first quarter of Budget Period one, there were ongoing contract negotiations with MPEC as the host site for the first CTI installation in Poland. Preliminary engineering was done concurrent to these negotiations. In addition, the transfer and development of training materials began.

In the second quarter, a contract with MPEC was signed which allowed commencement of other project work. This included putting subcontract agreements in place with other polish partners, completing engineering, revising and coordinating schedules and conducting some of the training.

By the end of the third quarter of Budget Periud One, $75 \%$ of the material was fabricated and $25 \%$ of the total macerial was shipped to the Balicka site. Baseline performance testing was conducted by the Politechnika on one steam and one rot water boiler. Classroom and in-plant training in the U.S. was provided to four key personnel from MPEC. Training materials and information transmitted from Penn state to the Politechnika were translated and adapted for use in the Polish culture and language. Efforts to secure sites for Budget Period Two began in the third quarter.

In this the fourth quarter, progress was made on several project tasks. Fabrication of all materials was finished in late November, 1994. However, shipments were not completed until the beginning of February. Installation began in October, 1994 and continued until December, 1994. At this point, installation halted for two months. This delay was because of problems with invoicing and payment of VAT. As a result, the contract between CTI and MPEC had to be amended and new subcontract agreements were written with ENAP and Naftokrak. This problem delayed the entire project for over two months.

Graded coal for the Balicka testing as specified in the contract between CTI and MPEC was obtained by MPEC, with the assistance of Mr. Uruski from Katowice.

Progress was made to secure sites for Budget Period Two of the project. John West and Tomasz Szewczyk had follow-up meetings 
with 3 possible sites, receiving 2 letters of intent.

During the fifth quarter the installation and performance of controls for the 5 boilers was virtually completed. Testing on a hot water boiler was accomplished. Graded coal was obtained, further operators trained, additional letters of intent, adoption of controls for Poland proceeded, and Tomasz Szewczyk continued as project coordinator.

During the sixth quarter we were originally told by BRK and Mr. Wertz that the Children's Hospital project would begin. However, Mr. Wertz changed his mind and refused. A trip to Warsaw was made to meet with the Director of the US Export - Import Bank (Julie Balaga) to help secure financing through BOS Bank for budget year 2 sites. Meetings were held with additional possible budget year 2 sites, along with a presentation with BRK and Dr. Thomas Butcher in Katowice, and with a Charnov boiler house.

In the next quarter we will continue to secure contracts for DOE year 2, get the steam boilers tested, and get the limited liability company registered and staffed. 


\subsection{INTRODUCTION}

Control Techtronics International. (CTI) is conducting a project to reduce air emissions and increase efficiency in coal fired boilers in Krakow, Poland and to create a commercial venture in Poland which can act as a leader for efficient combustion in boilers throughout the region. To achieve the technical goals of the project, CTI will use a three part program as follows:

1. Analyze the fuel specifications of a given plant and recommend modifications as necessary.

2. Apply automatic combustion controls systems to the boilers.

3. Train plant operators in proper plant operation as well as proper use of control systems.

To achieve the commercial goals, CTI will form a commercial venture in Poland to market and service the CTI program after successful demonstration.

In Budget Period One, CTI demonstrated the efficiency improvement and emission reduction at MPEC's Balicka district heating plant in the widok section of krakow. CTI worked with several organizations to accomplish this work. The Pennsylvania State University (PSU) provided technical assistance in analysis of the fuel quality, technical assistance in the application of the controls, training material and techniques, and project managenent assistance. The Folitechnika Krakowska (PK) conducted performance tests on the boilers at Balicka and conducted training in the Polish language. NaftokrakNaftobudowa (NK) was the installing contractor. MPEC is the owner of the host site for the first CTI installation. Energoparatura (ENAP) built the control panels that were engineered by CTI and contain both Polish and American components. CTI is also interfacing with the Honeywell system heating controls in the widok district. 


\subsection{DESCRIPTION OF ACTIVITIES DURING THE SIXTHQUARTER}

Progress was made on several project tasks during the fifth quarter. Fabrication of all materials was finished in late November, 1994. Shipments were not completed until the beginning of February. Installation began in October, 1994 and were completed in May, 1995. These delays were because of problems with invoicing and payment of VAT. As a result, the contract between CTI and MPEC had to be amended and new subcontract agreements were written with ENAP and Naftokrak. This problem delayed the entire project for over two months.

At the same time, problems arose regarding the availability of graded coal for the Balicka testing as specified in the contract between CTI and MPEC. With the help of Mr. Uruski in Katowice, graded coal was obtained.

Progress was made to secure sites for Budget Period Two of the project. Tomasz szewczyk presented proposals to these sites in January and February and received two letters of intent.

Analysis was made on the technical details as were accomplished in Baliska/MPEC. Technical areas which could best be modified for Polish work were defined, so that the adoption process to meet the Polish market has been completed. 


\subsection{Status of Tasks - Sixth Quarter}

Following is the status of completion for each task being worked on in Budget Year 2:

Task 1: Formation and Operation of a commercial Joint Venture.

CTI's cooperation with several Polish organizations has been essential to the work in Krakow. A continuing relationship with Naftokrak as the installing contractor, MPEC as the owner of the first demonstration site, and Tomasz Szewezyk as coordinator is desired. A limited liability company, is being negotiated.

Task 3: Installation and Start-up of Control Components.

Installation was completed, but start-up of hot water boilers won't be completed until cold weather returns.

Task 4: Procurement of Graded Coal.

Completed in April, 1995.

Task 6: Select and Train Polish Field and Marketing Engineer.

Tomasz Szewczyk continues to act as the main point of contact in Poland for CTI. Mr. Tomasz Szewczyk attended the CTI international sales meetings and the annual ASHRAE conference in Chicago in January, 1995 in an effort to extend his training. In this quarter Mr. Szewczyk became actively involved in selection of sites for Budget Period Two. Mr. Kalinowski of NK-NB became the start-up engineer. Both continue to learn, do well and their interest builds.

Task 7: Operator Training for Balicka Personnel

Training took place in Krakow for the operators during the fourth quarter at the same time as start-up of the first boiler. Further training must be accomplished when the boilers start-up this winter.

Task 8: Testing and Documentation of Performance at Balicka.

Final testing was conducted after start-up of the hot water boiler used in the baseline tests. Results were astonishing:

$25 \%$ Energy Reduction

$85 \%$ Particulate Reduction 
Steam boiler testing is scheduled for Fall 95

Task 10: Identify Other Plant Sites for Control Systems.

Five letters of intent have been received to date. One, (Children's Hospital) turned into a "pumpkin" as Mr. Wertz reversed his position and declined to fund cleaning up the air at Children's Hospital.

Task 12: Engineering, Fabrication of Shipment of Controls.

A small portion of this was accomplished at Balicka boiler house. The balance needs to be accomplished in the Winter when the work on Phase 2 sites begins.

Task 15: Joint Operator Training.

The initial operator training was very successfully accomplished. Further training will be needed in the Winter when the boilers at Balicka become operational full-time. 
5.0 NEXT QUARTER ACTIVITIES (MaY 15, 1995 to August 15, 1995)

The following are major activities that are anticipated to take place in the next quarter.

1. Close Budget Year 2 contracts.

2. Begin work on Budget Year 2 projects.

3. Sign papers for limited Iiability company.

4. Establish financing for Polish customers. 


\subsection{Foreign Travel Report.}

John West of CTI was in Poland the last two weeks of June to meet with Polish participants in the project. Frank Carroll visited in July to assist at start-up and visit possible budget year 2 sites. The approximate cost of each trip was $\$ 1,900$. Several project meetings were held including meetings with MPEC, Naftokrak, The Politechnika, BRK, and prospective customers both in the Krakow and Katowice region. 